\title{
THE RECOVERY OF THE TOURISM INDUSTRY IN BALI PROVINCE THROUGH THE PENTA-HELIX COLLABORATION STRATEGY IN THE NEW NORMAL ERA
}

\author{
Made Kembar Sri BUDHI \\ Udayana University, Faculty of Economics and Business, Denpasar, Indonesia, e-mail: kadek_dedek@unud.ac.id \\ Ni Putu Nina Eka LESTARI \\ Undiknas University, Faculty of Economics and Business, Denpasar, Indonesia, e-mail: nina@ undiknas.ac.id \\ Ni Nyoman Reni SUASIH* \\ Udayana University, Faculty of Economics and Business, Denpasar, Indonesia, e-mail: renisuasih@unud.ac.id
}

\begin{abstract}
Citation: Budhi, M.K.S., Lestari, N.P.N.E., \& Suasih, N.N.R. (2022). THE RECOVERY OF THE TOURISM INDUSTRY IN BALI PROVINCE THROUGH THE PENTA-HELIX COLLABORATION STRATEGY IN THE NEW NORMAL ERA. GeoJournal of Tourism and Geosites, 40(1), 167-174. https://doi.org/10.30892/gtg.40120-816
\end{abstract}

\begin{abstract}
Tourism is a leading sector that makes an important contribution to regional economic growth in the Province of Bali. During the global COVID-19 pandemic, Bali tourism experienced a very drastic decline. The COVID-19 pandemic has an impact on all industries, including the tourism industry. This study aims to formulate a recovery strategy for the tourism industry in Bali Province in the short, medium and long term, in the New Normal Era. The type of data that will be used is perception data and existing data so that the analytical method used in this study is a quantitative approach in the form of descriptive qualitative and SWOT. Based on the results of data analysis, it can be concluded that each penta-helix element plays an important role in efforts to recover Bali tourism in the new normal era according to its auth ority and capability. Strategies/policies that are considered as short-term priorities are the provision of subsidized interest and credit restructuring. Meanwhile, what is considered a priority for the medium term is the organization of international events as well as training and internship cooperation for tourism human resources and the creative economy. The penta-helix element generally considers strengthening access and strengthening attractions as long-term priorities.
\end{abstract}

Key words: tourism recovery, penta-helix, new normal era, strategy, SWOT

$* * * * *$

\section{INTRODUCTION}

Tourism is a leading sector that makes an important contribution to regional economic growth in Bali Province (Antara and Sumarniasih, 2017; Wijaya et al., 2020). This is supported by the availability of natural resources and socio-cultural communities that have a unique and noble culture, so that they become attractive tourist destinations for domestic and foreign tourists (Suasih et al., 2017). The tourism sector as the largest contributor to Gross Regional Domestic Revenue in Bali Province, followed by the agricultural sector and the industrial sector (Soritua, 2015).

The competitiveness of the tourism sector in Bali Province is very large. However, during the global pandemic due to Corona Virus Diseases-2019 (COVID-19), Bali tourism experienced a very drastic decline (Suasih et al., 2021). The COVID-19 pandemic has an impact on all industries in Bali Province and even the world, including the tourism industry. The impact of Covid-19 on tourism is very large because the tourism industry is closely related to other industries, namely Hospitality, Transportation, Micro, Small and Medium Enterprises (MSMEs), especially those that produce handicrafts, souvenirs, culinary, restaurants, travel agencies, and tour guides. Although Bali has experienced sluggishness before, namely the Bali Bombings in 2002 and 2005 and the eruption of Mount Agung in 2017, this pandemic resulted in 3,060 workers in Bali experiencing layoffs, and there were 77,307 workers in the tourism sector, such as hotels, restaurants and staff. tourism guides are laid off (Suasih and Wijaya, 2021).

The COVID-19 pandemic, which had a significant impact on the tourism sector, caused economic growth to experience a sharp decline. BPS Bali Province recorded that Bali's economic growth in the first quarter of 2020 was $1.14 \%$ year on year (yoy), lower than Indonesia's economic growth. In addition, economic growth in the first quarter of 2020 was recorded as the first negative growth in a decade. The magnitude of the impact of the global COVID-19 pandemic in the world is thought to have caused major shocks (negative shocks) to the global, national, and regional economies. Even in the second quarter of 2020, Bali's economic growth contracted deeper by -10.98\% (yoy) (Statistics Indonesia, 2020).

The Bali Provincial Government has acted quickly by taking policies to deal with the impact of COVID-19, in the form of budget relocation to support policies in the health, economy, social safety nets and policies in the tourism sector (Suasih and Wijaya, 2021). Policies in the field of tourism, in particular, the Central Government through the Minister of Finance of the Republic of Indonesia, has approved the proposed tourism grants affected by COVID-19 for regencies/cities throughout Bali, as areas that become tourism destinations that are experiencing the impact of financial

\footnotetext{
* Corresponding author
} 
disturbances, and a decrease in Regional Original Income and has an impact on to tourism businesses. The Tourism Grant is allocated for tourism business actors by $70 \%$ and the Regency/City Government by $30 \%$.

In connection with efforts to recover tourism to be able to increase PAD in Bali Province in the New Normal era or a new life order which is currently being drafted by the government to overcome the Bali economy due to the Covid-19 pandemic, there is a lot of discussion among the public. The community must now prepare for the New Normal Era to live side by side with COVID-19. One of them is in the tourism sector by opening tourist destinations and the implementation of special health protocols in the tourism sector. Several MSMEs and the tourism sector experienced significant changes during this pandemic, especially during the New Normal (Wijaya and Suasih, 2020). New Normal policies and arrangements have been prepared, especially in the tourism sector, in this case the Ministry of Tourism and Creative Economy has compiled a CHS (Cleanliness, Health and Safety) program as a new normal order in tourist destinations by involving tourism industry players and the creative economy which is expected to be tourism can be productive and safe from COVID-19. All programs that have been prepared and planned by the Bali provincial government in their implementation require support and synergy between sectors and related parties, such as academics, government, business circles and media groups and customers. According to Pitana and Diarta (2009), there are many positive impacts of tourism on the economy, including income from foreign exchange, healthy foreign trade balance, income from tourism businesses, government revenues, employment, multiplier effect, and utilization tourism facilities by local communities. With so many tourism potentials in the Province of Bali, it is hoped that the income of an area and the surrounding community can increase as tourists arrive, for this reason, consolidation between elements in the penta-helix model is needed, namely the role of business, government, community, academic, and media (BGCAM). The government's role in tourism development in the era of the new normal is very crucial, so that the program is successful. Therefore, it is very interesting to study about Tourism Industry Recovery in Bali Province through the penta-helix collaboration strategy. The purpose of this study is to analyze and formulate a recovery strategy for the tourism industry in Bali Province in the short, medium and long term, in the new normal era so that it can be used as a reference in making strategic decisions for the Government.

\section{MATERIALS AND METHODS}

\section{A. Concept of Tourism}

Kodhyat (1998) states that tourism is a journey from one place to another, temporary in nature, carried out by individuals or groups, as an effort to find balance or harmony and happiness with the environment in the social, cultural, natural and scientific dimensions. Meanwhile, Murphy (1985) defines the tourism sector as a whole of elements related to tourists, tourist destinations, travel, industry and others, which are the result of tourist trips to tourist destinations as long as the trip is not permanent. Tourism is a system that includes tourists and the services provided (in the form of facilities, attractions, transportation, and accommodation) to satisfy and support their journey. Furthermore, Marpaung (2002) defines tourism as a temporary movement carried out by humans with the aim of getting out of their routine work, or also from their place of residence. In this regard, Soekadijo (2000) said that the tourism sector is all community activities related to tourists. Because tourism consists of various organizational activities that provide goods and services to tourists, such as tourist transportation, accommodation, human attractions and natural attractions, personal services and government services, intermediaries such as traders and travel agents, the tourism sector is often called the tourism industry (Bull, 2011).

In tourism activities there are several parties who have a role and are directly involved in tourism activities. The following picture illustrates the illustration of stakeholders in tourism (Sunaryo, 2013).

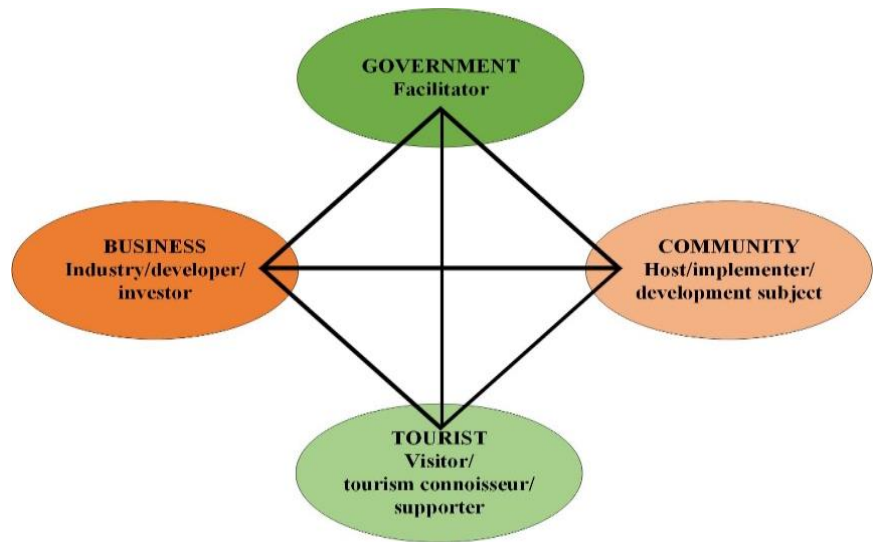

Figure 1. Stakeholders in Tourism

(Source: Sunaryo, 2013; has been reprocessed)

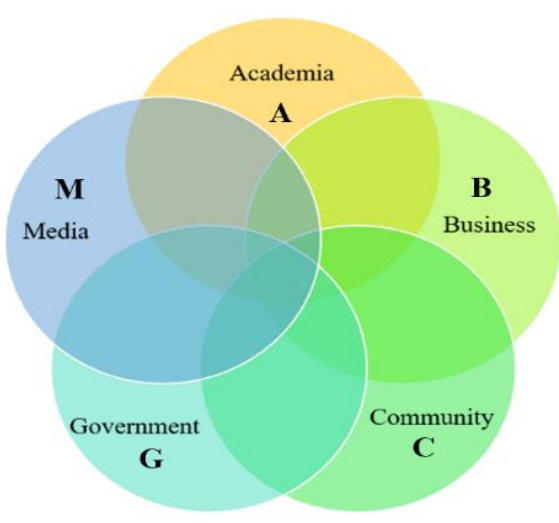

Figure 2. Penta-helix Model Collaboration (Source: Vani et al., 2020; has been reprocessed)

\section{B. Penta-helix Model}

Penta-helix is an extension of the triple-helix strategy by involving various elements of society and non-profit institutions in order to realize innovation (Lindmark et al., 2009). Through this synergistic collaboration, it is hoped that an innovation will be realized that is supported by various resources that interact synergistically. Triple-helix was first introduced by Etzkowitz and Leydesdorff in 1995, with elements of academic, business sector, and government. Triplehelix was then developed again with one element added, Civil Society or a community which became the quadruple-helix, 
to accommodate the community's perspective. The quadruple-helix concept was developed by maintaining the interaction of the triple helix model (science and technology network between universities, industry, and government) and involving civil society as a whole in the system. In Indonesia, the quadruple-helix model was then added to one more element, namely media which later became a complement to the penta-helix element because in the context of developing the creative economy in Indonesia, the media (both conventional media and social media) played a significant role even though they remained an independent element or were not directly affected. by other elements in carrying out their part or function.

Based on some of the explanations above, it can be concluded that penta-helix is an innovation model that is used in order to improve or develop the economic level of a country or region which involves five stakeholders, namely government, business (private), media, academics and the community, where the five These elements have their respective messages and influence which is quite large and influential so that when combined in a collaboration with a specific purpose, better and maximum results will be obtained. The concept of penta-helix in Indonesia began to be developed in 2016 through the idea of Minister of Tourism with the synergy of ABCGM (academician, business, community, government, and media) which then these five elements were eventually used as a model for tourism development. The idea is stated in the Minister of Tourism Regulation of the Republic of Indonesia Number 14 of 2016 concerning Guidelines for Sustainable Tourism Destinations. The following is an overview of the penta-helix model from the Minister of Tourism of the Republic of Indonesia. According to Soemaryani (2016), the penta-helix model is a reference in developing synergies between related agencies in supporting as optimally as possible in order to achieve goals. It is clear that penta-helix collaboration has an important role to play in supporting the goals of shared innovation and penta-helix contributing to regional socio-economic progress. The following is the role of each element of the penta-helix, as follows.

1) Government, acts as a regulator as well as acts as a controller that has regulations and responsibilities in developing objects. In this case it involves all types of activities such as planning, implementation, monitoring, control, promotion, financial allocation, licensing, programs, legislation, development and knowledge, public innovation policy, support for innovation networks and public-private partnerships. The government also has a role in coordinating the stakeholders who contribute to the development of the collaboration.

2) Business (Private), acts as an enabler. Business is an entity that carries out business processes in creating added value and maintaining sustainable growth (Slamet et al., 2016). Business acts as an enabler that provides infrastructure, by supporting changes in business human resources in collaborative governance, while also acting as a budget promoter in providing added value or income in the form of funding for the development of the sector.

3) Academia, act as drafters, such as standardizing the process for the activities carried out as well as certification and human resource skills (Slamet et al., 2016). Academics in this case are a source of knowledge by using the latest concepts, theories relevant to activities or sectors developed to gain a sustainable competitive advantage.

4) Media, acts as an expander, in this case the media plays a role in supporting publications in promotion and creating brand image. In the cooperation development program. Media can be said to be a fairly influential element in tourism development, it is because of the influence of very modern developments so that technology and media dominate so that what is rumored in the media becomes a topic that is quite influential and has a very good effect on tourism.

5) Community, acts as an accelerator. In this case the community is people who have the same interests and are relevant to a growing business (Slamet et al., 2016). The community can also act as an intermediary or as a liaison between stakeholders to assist the development process of the sector. The community here can include the official community or the community which has an important role in the development of the cooperation.

\section{Method}

Data collection techniques include documentation studies, questionnaires, observations, interviews and Focus Group Discussions (FGD). FGD is almost the same as collecting data through interviews, namely to uncover people's perceptions and values, but if the interviews are one-to-one, while the FGDs are group interviews (Nyumba et al., 2017). The parties involved in this research FGD are elements of academics (socio-economic field), business elements (tourism entrepreneurs), community (community leaders in tourist areas), government (Bali Provincial Government), and media (journalists). The data obtained in this study were quantified so that they could be analyzed quantitatively, for further interpretation. Descriptive statistical analysis is a statistic used to analyze data by describing the data that has been collected as it is without intending to make conclusions that apply to the public or generalizations. Descriptive analysis is central to almost every research project and an essential component of high-quality causal analysis.

Descriptive analysis also characterizes the phenomena and identify patterns to answer questions about who, what, where, when, and to what extent (Leob et al., 2017). Analysis of Strengths-Weaknesses-Opportunities-Threats (SWOT) is used to analyze the potential and challenges in the recovery of the tourism industry in Bali. SWOT analysis is the identification of various factors systematically to formulate strategies, plans, and countermeasures based on the results of the data (Wang and Wang, 2020). SWOT analysis is based on the thinking that, in determining the policy strategy to be implemented, an organization must maximize its strengths and opportunities, while simultaneously minimizing existing weaknesses and threats to achieve a balance between internal conditions and external conditions (Dahliah et al., 2020).

\section{RESULTS AND DISCUSSION}

\section{A. Bali Tourism in the New Normal Era}

Before pandemic, Bali's Tourism is one of the most popular tourist destinations in the world. The alluring charm emanates from the beauty of the island of Bali. Many charms that spoil the eye that can be enjoyed in Bali. The beauty of the beaches, to 
the culture on the island of Bali. The development of Bali tourism from year to year is strongly influenced by the cultural diversity of the Balinese people. Balinese customs, arts, and culture as the dominant basic potential in it implied an ideal of a reciprocal relationship between tourism and culture. This is one of the unique characteristics compared to other destinations in Indonesia (Paramita and Putra, 2020). As previously discussed, the travel and tourism sector has been greatly affected by the COVID-19 pandemic (Sugihamretha, 2020). As a result of the COVID-19 pandemic, cumulative foreign tourist visits to Bali in 2020 reached 1,069,473 people, but indeed this number was dominated by foreign tourist visits in the first quarter (January-March) 2020. Figure 3 presents the number of direct foreign tourist visits to Bali. Bali in 2020-2021 (May).

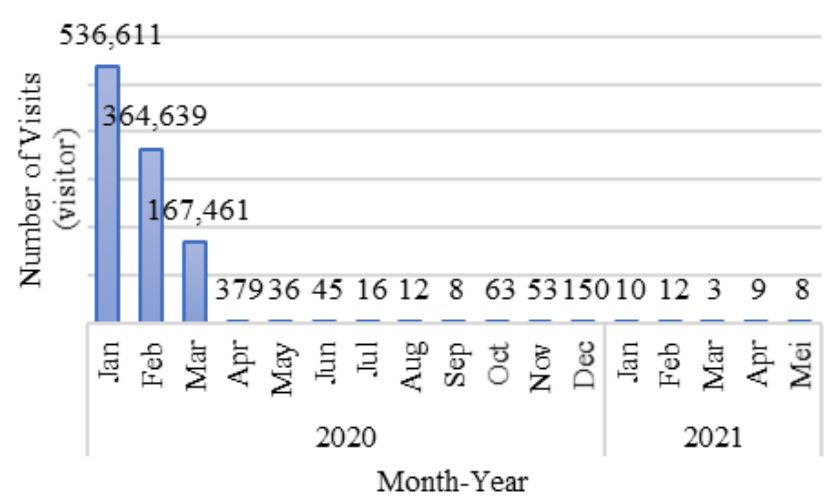

Figure 3. Number of Direct Foreign Tourist Visits to Bali 2020-2021

(Source of Data: Statistics of Indonesia of Bali Province, 2021)

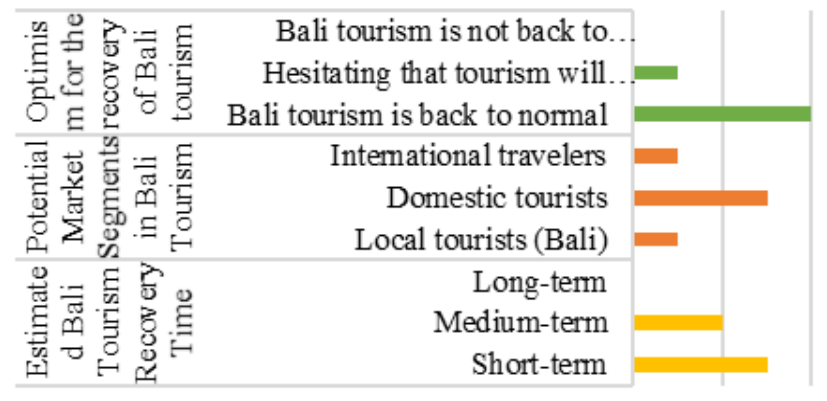

$40 \quad 80$

(\%)

Figure 4. Survey Results Regarding Bali Tourism in the New Normal Era (Source: Tabulation of data from the questionnaire, 2021)

Figure 3 clearly shows that since the beginning of 2020 the number of foreign tourists visiting Bali began to decline, even drastically in April 2020. Until mid of 2021 (May 2021), the number of foreign tourists visiting Bali was only 42 people. This is of course as a result of social restrictions, closing access to Bali, travel restrictions, and the general public's perception of the dangers of a pandemic (Ministry of National Development Planning of the Republic of Indonesia, 2021). The decline in tourist visits (especially foreign tourists) has an impact on the accommodation sector. Hotel occupancy in Bali has fallen. up to 80\%-90\%, some even close their hotel business (Ministry of Tourism and Creative Economy of the Republic of Indonesia, 2021). Globally, it is not known when the COVID-19 pandemic will end so that the global community is expected to be able to adapt by implementing a new lifestyle. Referring to global developments, tourism businesses must also implement a new protocol pattern as part of an effort to survive and maintain the sustainability of the tourism sector. In this regard, Ministry of Tourism and Creative Economy of the Republic of Indonesia has issued guidelines related to tourist travel protocols, especially in Bali Province during the new normal period. In general, tourist travel protocols in Bali Province are regulated by prioritizing efforts to prevent the spread of COVID-19 with the main activities:

1) Wear a mask;

2) Frequent hand washing/hand sanitizer;

3) Keep your distance (physical distancing/social distancing).

The tourist travel protocol is regulated in two major parts, namely:

1) Arrival flow consisting of pre-departure, arrival and accommodation.

2) The return route consisting of the time at the hotel, airport and plane.

The Deputy Governor of Bali (in mediaindonesia.com) said that there are three important aspects that need to be prepared for Bali tourism in the new normal era, namely time, cost, and human resources. Regarding time, it is necessary to think about when is the right time for Bali to open again. While the cost aspect is the changes in health protocols that are demanded in the new normal era, it is necessary to recalculate the costs required for all tourism business services. Meanwhile, human resources need to prepare human resources who understand health protocol standards. When discussing the new normal era, namely a situation where changes in people's behavior are followed. For this reason, tourism service business actors need to prepare three basic things that become priorities to support the tourism sector, namely attention to cleanliness, health and safety. Furthermore, the Deputy Governor of Bali also conveyed the strategy he wanted to implement for the tourism sector in the new normal era, namely knowing clearly the market potential, such as at the beginning, namely the domestic market, as well as SOPs that would be implemented, as well as dealing with costs that would be imposed, and establishing cooperation with other parties. competent parties such as banks that can support the growth rate of Bali tourism. Based on the results of data analysis obtained through questionnaires, it is known that there are several opinions regarding the sustainability of Bali tourism in the new normal era. So far, tourist attractions in Bali are very diverse, both in door and out door. According to the results of data collection, it turned out that all respondents agreed that the type of out-door tourist attraction would develop in tourism in the new normal era. This is triggered by tourists' perceptions of healthy, green or environmental-themed tourism, thus providing a sense of security for traveling. The opinion of the penta-helix element regarding Bali tourism in the future, namely in the new normal era illustrates that there will be some shifts in the form and pattern of Bali tourism before the COVID-19 pandemic. One of them is clear on the application of health protocols from arrival until tourists complete tourist activities, including when traveling at tourist attraction locations. In addition, in the short term it is suspected that there will be a shift in the dominant tourist market share, which was previously dominated by foreign tourists, but in the future domestic and local tourists also need to be "worked on" considering that many countries still impose travel restrictions. 


\section{B. Identification of Bali Tourism SWOT in the New Normal Era}

Based on the results of the FGD, internal factors (in the form of strengths and weaknesses) and external factors (in the form of opportunities and threats) in Bali tourism in the new normal era can be identified. Furthermore, based on the description in Table 1, a SWOT matrix can be arranged.

Table 1. Identification of Internal and External Factors in Bali Tourism in the New Normal Era

\begin{tabular}{|c|c|c|}
\hline \multicolumn{2}{|c|}{ Factors } & Description \\
\hline \multirow{2}{*}{ 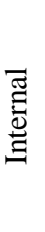 } & Strengths & $\begin{array}{l}\text { - Strong culture and natural potential that can still be developed for Bali tourism in the new normal era. } \\
\text { - Bali became the initial pilot for mass vaccination in Indonesia. } \\
\text { - Bali is also considered the best in handling the COVID-19 pandemic. }\end{array}$ \\
\hline & $\begin{array}{l}\text { Weak- } \\
\text { nesses }\end{array}$ & $\begin{array}{l}\text { - The government and tourism actors have never previously prepared the concept of disaster mitigation in the tourism sector. } \\
\text { - Society has been relying too much on tourism with high economic value. } \\
\text { - Many people's character has not dared to try new things. } \\
\text { - Slow skill upgrades if they are not directly related to the tourism sector. }\end{array}$ \\
\hline \multirow[b]{2}{*}{ 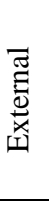 } & $\begin{array}{l}\text { Oppor- } \\
\text { tunities }\end{array}$ & $\begin{array}{l}\text { - The market share of domestic tourists is still very promising. } \\
\text { - Tourism in the new normal era will have the opportunity to bring in quality tourists because they are in good health. }\end{array}$ \\
\hline & Threats & $\begin{array}{l}\text { - There are still travel restrictions from the country of origin of foreign tourists who previously visited Bali a lot. } \\
\text { - Mass tourism will decrease. } \\
\text { - Convincing tourists to feel safe and comfortable about the health and cleanliness of tourism products in Bali. } \\
\text { - Competition with other tourist destinations, both domestically and abroad. }\end{array}$ \\
\hline
\end{tabular}

Table 2. SWOT Matrix of Bali Tourism in the New Normal Era

\begin{tabular}{|c|l|l|}
\hline $\begin{array}{l}\text { SWOT } \\
\text { Matrix }\end{array}$ & \multicolumn{1}{|c|}{ Strengths - S } & \multicolumn{1}{|c|}{ Weaknesses - W } \\
\hline & $\begin{array}{l}\text { S-O Strategy: } \\
\text { Optimizing the promotion of natural and cultural tourism, as well as } \\
\text { public health to provide a sense of security for traveling so that in the } \\
\text { early stages of recovery it is able to bring in domestic tourists. }\end{array}$ & $\begin{array}{l}\text { W-O Strategy: } \\
\text { Preparing the tourism mitigation concept to bring } \\
\text { in quality tourists. }\end{array}$ \\
\hline 1 & $\begin{array}{l}\text { S-T Strategy: } \\
\text { Optimizing, refocusing, and implementing health protocols on various tourist } \\
\text { objects/attractions so that they can compete with tourist destinations } \\
\text { outside Bali and provide a sense of security and comfort for tourists. }\end{array}$ & $\begin{array}{l}\text { W-T Strategy: } \\
\text { Upgrade skills and innovation in business (especially } \\
\text { tourism) so that it can attract quality tourists } \\
\text { (because it is no longer a mass tourism pattern). }\end{array}$ \\
\hline
\end{tabular}

Table 3. The Role of Penta-helix in Bali Tourism and Tourism Recovery (Source: Jahid, 2019; Rizkiyah et al., 2019; Own elaborated)

\begin{tabular}{|c|c|c|c|}
\hline No. & Penta-helix Elemen & Role in Tourism & Role in Bali Tourism Recovery \\
\hline 1. & Government & $\begin{array}{l}\text { - Development of tourism through: regulation, } \\
\text { guidance, implementation, and supervision. }\end{array}$ & $\begin{array}{l}\text { - Develop and implement standardization policies; } \\
\text { tourist spot CHSE certification. } \\
\text { - Issue policies that support credit to entrepreneurs and } \\
\text { transfer of rural funds. }\end{array}$ \\
\hline 2. & $\begin{array}{l}\text { Business/ Industry/ } \\
\text { Private Sector }\end{array}$ & $\begin{array}{l}\text { - Creating job opportunities. } \\
\text { - Recruitment of local human resources as } \\
\text { tourism industry players. }\end{array}$ & $\begin{array}{l}\text { - Make a breakthrough in the type of business that is in } \\
\text { accordance with Health standards. } \\
\text { - Using a touch of technology in business. } \\
\text { - Implementing Health protocols in business. }\end{array}$ \\
\hline 3. & Academia & $\begin{array}{l}\text { - Implementing training and development of } \\
\text { tourism human resources. } \\
\text { - Implementing scientific studies. } \\
\text { - Implementing socialization and assistance to } \\
\text { community groups. }\end{array}$ & $\begin{array}{l}\text { - Providing policy input based on studies conducted. } \\
\text { - Provide data and input related to the needs of the new } \\
\text { era of tourism. }\end{array}$ \\
\hline 4. & $\begin{array}{l}\text { Local } \\
\text { Communities/ } \\
\text { Balinese }\end{array}$ & $\begin{array}{l}\text { - Role as business actors who are engaged } \\
\text { directly/indirectly in the tourism industry. } \\
\text { - Monitor the impact of tourism on the culture } \\
\text { and social community. }\end{array}$ & $\begin{array}{l}\text { - Discipline in applying health protocols, especially in } \\
\text { tourist attractions. } \\
\text { - Support government policies. }\end{array}$ \\
\hline 5. & Media & $\begin{array}{l}\text { - Promotional instruments, information } \\
\text { distribution and tourism image improvement. }\end{array}$ & $\begin{array}{l}\text { - As a medium for promoting healthy tourism. } \\
\text { - Creating community comfort with constructive news. } \\
\text { - Reporting on the efforts that can be taken for economic } \\
\text { recovery so that it is easily accessible to all parties. }\end{array}$ \\
\hline
\end{tabular}

Based on Table 3, it is known that the Bali tourism recovery strategy in the new normal era. Where each strategy is designed according to the characteristics of the previously identified SWOT factors.

\section{The Role of Penta-helix in Bali Tourism Recovery}

In an effort to recover Bali's tourism, it requires the synergy of all parties in this effort. Quoted from Jahid (2019), the history of the development of the concept of synergy in tourism development began with the idea of a triple-helix which was adopted from the theory of Etzkowitz and Leydesdorff (2000). This triple helix concept emphasizes the relationship between universities, industry and government. In 2014, Lindberg developed a new concept called the quadruple helix by adding elements of the local community as a complement to the triple-helix concept that had already developed. Meanwhile, the penta-helix concept was proposed by Riyanto (2018) by involving the media, which currently plays a very significant role in developing social capital for development. 
Based on the results of the literature review and FGD, Table 3 below presents the role of each element in the pentahelix in tourism in general, and in particular in the recovery of Bali tourism. Each penta-helix element has its own role in the restoration of Bali tourism which is adjusted to the authority and capability of each penta-helix element.

\section{Bali Tourism Recovery Strategy}

Bali tourism recovery strategies are classified into short-term, medium-term, and long-term strategies. Based on the results of the FGD with penta-helix, it is possible to identify the Bali tourism recovery strategy in the new normal era as presented in Table 4.

Table 4. Bali Tourism Recovery Strategy Formulation in the New Normal Era (Source: Processed by Researchers, 2021)

\begin{tabular}{|c|c|c|}
\hline Classification & Description & Code \\
\hline \multirow{7}{*}{ Short-Term } & 1) Reorientation to quality tourism, not only mass tourism. & S1 \\
\hline & $\begin{array}{l}\text { 2) Provision of subsidized interest and credit restructuring (loans and multi-finance) to Micro, Small, and } \\
\text { Medium Enterprises (MSMEs) in banks or other financing institutions, including for subsidies/deferred taxes for } \\
\text { SMEs as well as labor. }\end{array}$ & $\mathrm{S} 2$ \\
\hline & $\begin{array}{l}\text { 3) Incentives for recruitment, certification training and placement of workers through expansion of education and } \\
\text { training including technical guidance on making long stay service packages for self-isolation. }\end{array}$ & S3 \\
\hline & $\begin{array}{l}\text { 4) Facilitation of local governments to continue the development of } 3 \mathrm{~A} \text { (accessibility, amenities and attractions) } \\
\text { that are affected by the termination of the Special Allocation Fund for physical tourism, with special attention to } \\
\text { facilitation of cleanliness. }\end{array}$ & S4 \\
\hline & 5) Acceleration of infrastructure development in priority destinations. & S5 \\
\hline & 6) Tourism promotions, exhibitions and events are gradually being activated. & S6 \\
\hline & $\begin{array}{l}\text { 7) Increasing incentives for tourism business actors, airlines, travel agents, and promotions in the form of } \\
\text { discounted airline tickets and discounts on jet fuel at several priority tourism destination airports, providing } \\
\text { incentives for group incentive trips/fam-trips held in Indonesia. }\end{array}$ & S7 \\
\hline \multirow{11}{*}{$\begin{array}{l}\text { Medium- } \\
\text { Term }\end{array}$} & $\begin{array}{l}\text { 1) Providing tourist discounts for students, ASN and TNI/POLRI, health workers and senior citizens as well as } \\
\text { the application of leave and public holidays that support the increase in domestic tourists. }\end{array}$ & M1 \\
\hline & 2) Marketing to near and recovered originations. & M2 \\
\hline & $\begin{array}{l}\text { 3) Increased incentives for tourism business actors, airlines, travel agents, and promotions in the form of } \\
\text { discounts on airplane tickets, airplane parking and discounts on jet fuel at several priority tourism destination } \\
\text { airports, providing incentives for group incentive trips/fam-trips held in Indonesia, promotions through influencers. }\end{array}$ & M3 \\
\hline & 4) Cooperate with airlines for recovery and addition of flight schedules. & M4 \\
\hline & $\begin{array}{l}\text { 5) Organizing international events such as sports, arts and MICE (Meeting, Incentive, Convention, and } \\
\text { Exhibition), including the successful implementation of Moto GP, U-20 World Cup, and others. This promotion } \\
\text { of Indonesian tourism to the international world must be equipped with things that are able to show an increase in } \\
\text { the standards of cleanliness, health, and safety of visitors in Indonesia. }\end{array}$ & M5 \\
\hline & $\begin{array}{l}\text { 6) Improvement of } 3 \mathrm{~A} \text { infrastructure (amenities, accessibility, and attractions) in tourism destinations through } \\
\text { APBN, transfer funds, APBD, BUMN, private sector and PPP. }\end{array}$ & M6 \\
\hline & $\begin{array}{l}\text { 7) Incentives for recruitment, training, certification and placement of workers through the expansion of } 3 \text {-in-1 } \\
\text { education and training for as many as } 100,000 \text { workers. }\end{array}$ & M7 \\
\hline & $\begin{array}{l}\text { 8) Cooperation in training and internships for tourism human resources and the creative economy, including } \\
\text { technical guidance on improving health, hygiene, and safety standards, especially for MSME actors. }\end{array}$ & M8 \\
\hline & 9) Increased bidding for the implementation of international MICE in Indonesia. & M9 \\
\hline & 10) Escort the realization of large-scale tourism investment. & M10 \\
\hline & 11) Increasing access to financing for tourism business actors and creative actors both to banking and non-banking. & M11 \\
\hline \multirow{6}{*}{ Long-Term } & $\begin{array}{l}\text { 1) Strengthening the supply side (It is carried out through standardization policy interventions related to household } \\
\text { services, including those related to the provision of accommodation and food and drink. In addition, it is also necessary } \\
\text { to establish a tourism school curriculum that is ready to work from the beginning of the semester. Various facilities for } \\
\text { supporting economic facilities need to be implemented immediately to the tourism sector, such as tax holidays in the } \\
\text { context of investment in the tourism sector, export credit facilities for tourism actors (related to service exports), as } \\
\text { well as electricity (energy) tariffs that are specified outside peak load times for tourism business actors). }\end{array}$ & L1 \\
\hline & $\begin{array}{l}\text { 2) Strengthening Attractions (Can be done through a variety of types of tourism such as cultural tourism, } \\
\text { education, sports, health, history, etc. Diversification of tourist attractions also needs to be done in Special } \\
\text { Economic Zones (SEZ)/tourist locations). }\end{array}$ & L2 \\
\hline & $\begin{array}{l}\text { 3) Strengthening Access (What needs to be done are: 1) Improvement of connectivity between transportation } \\
\text { modes in order to balance the development of physical infrastructure; 2) Optimizing the use of information } \\
\text { technology in the context of harmonization of information on the tourism agenda in all regions; and 3) Better } \\
\text { synergize the travel calendar). }\end{array}$ & L3 \\
\hline & $\begin{array}{l}\text { 4) Strengthening the demand side (preferably through optimizing the potential of domestic tourists, tourist cards } \\
\text { for students and senior citizens as well as tourism discount cards for the general public). }\end{array}$ & L4 \\
\hline & 5) Refocusing Bali tourism into quality tourism (medical, maritime, MICE, nomadic tourism). & L5 \\
\hline & $\begin{array}{l}\text { 6) Carry out green recovery for Bali tourism (through the preparation of standards, implementation, and } \\
\text { arrangement of tourist attractions and natural tourism potential). }\end{array}$ & L6 \\
\hline
\end{tabular}

The penta-helix element involved in the FGD identified the formulation of Bali tourism recovery policy strategies in the new normal era into three classifications, namely long-term, medium-term, and short-term strategies/policies. To position each of these policies in each category, the penta-helix element also gives weight to the assessment, where the results are presented in Figure 5, Figure 6, and Figure 7. As presented in Figure 5, it can be seen that each penta-helix element provides a different assessment of each strategy/policy choice. In general, the strategies/policies that are considered as priorities are the provision of subsidized interest and credit restructuring (S2). Almost all elements of penta-helix position the 
strategy/policy of providing subsidized interest and credit restructuring as a priority, except for the academic element. Where academic elements position reorientation strategies/policies on quality tourism (not only mass tourism) as a priority.

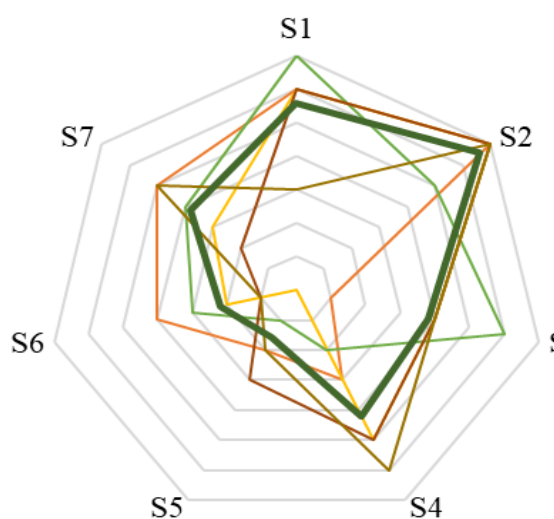

Figure 5. Chart of Priority Mapping of Bali Tourism Recovery Short-Term Strategy

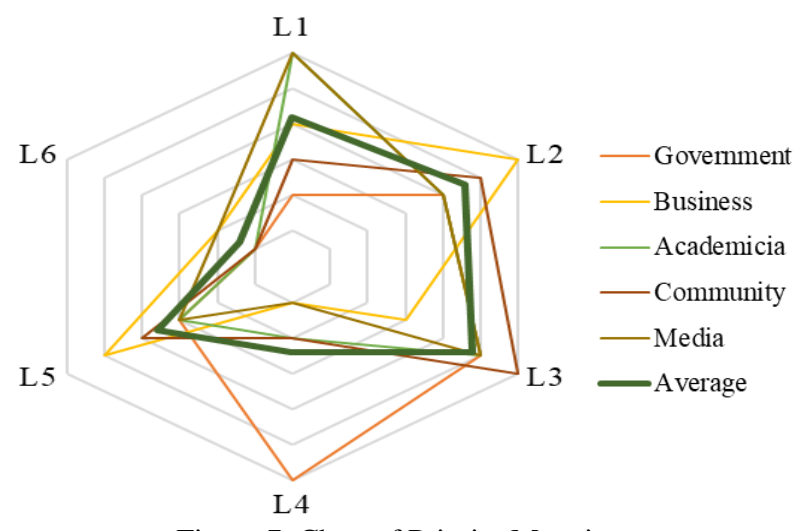

Figure 7. Chart of Priority Mapping

Long-Term Strategy for Bali Tourism Recovery

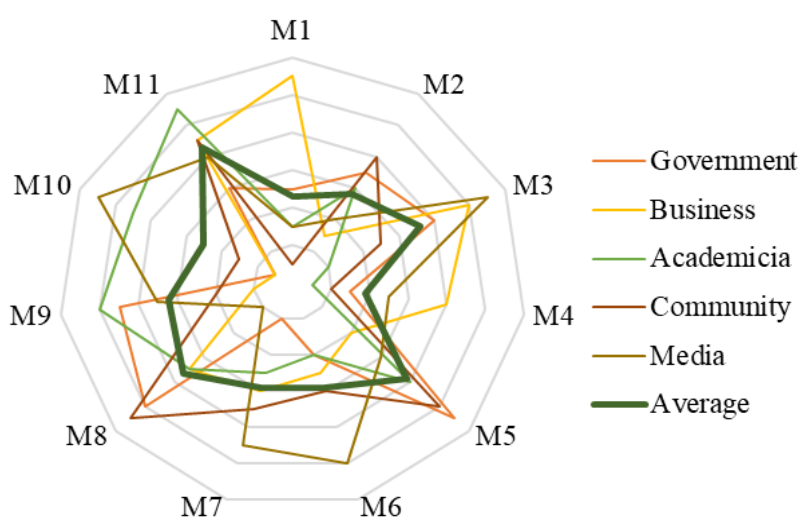

Figure 6. Chart of Priority Mapping of

Bali Tourism Recovery Medium Term Strategy

Furthermore, Figure 6 presents the position of the Bali tourism recovery strategy/policy in the medium term. On average, the chosen strategy/policy for the medium term is the organization of international events (M5) as well as training and apprenticeship cooperation for tourism and creative economy (M8) human resources. Government elements prioritize strategies/policies for organizing international events (M5). Meanwhile, industrial/private elements prefer to give tourism discounts for potential tourists (M1). Furthermore, academic elements prioritize increasing access to financing for tourism and creative economy actors (M11). In contrast, the community prefers a strategy/policy for cooperation in training and internships for tourism human resources and the creative economy (M8). The media elements consider increasing incentives for tourism business actors (M3) as a priority. Figure 7 shows the mapping of long-term strategy/policy priorities for Bali tourism recovery in the new normal era. The penta-helix element generally considers strengthening access (L3) and strengthening attractions (L2) as priorities. The government considers the priority strategy/policy is to strengthen the demand side (L4). Meanwhile, the industry/private sector prefers strengthening attractions (L2) as a priority. Furthermore, academics and the media chose to strengthen the supply side (L1). However, the community believes that the priority strategy/policy that needs to be carried out in the long term is to strengthen access (L3).

\section{CONCLUSION}

Based on the results of data analysis and discussion, as well as the research objectives as described previously, it can be concluded that each penta-helix element plays an important role in efforts to recover Bali tourism in the new normal era. The role is adjusted to its authority and capability, where the government, especially in terms of drafting regulations and their implementation, the private sector/industry plays a role in the provision and innovation of tourism businesses and their supporters, then academics play a role in conducting studies for basic policy input and improving human resource competencies. Furthermore, the community also plays an important role in supporting a conducive healthy tourism climate, as well as the role of the media in disseminating positive information and promoting Bali tourism.

Bali tourism recovery strategies/policies can generally be divided into short-term, medium-term, and long-term strategies/policies. Strategies/policies that are considered as short-term priorities are the provision of subsidized interest and credit restructuring. Meanwhile, what is considered a priority for the medium term is the organization of international events as well as training and internship cooperation for tourism human resources and the creative economy. The pentahelix element generally considers strengthening access and strengthening attractions as long-term priorities.

Some things that can be recommended as a follow-up to the results of this study are as follows.

1) The government needs to facilitate the preparation of tourism mitigation as an effort to mitigate the impact of disasters on tourism.

2) The Bali Provincial Government can prepare a roadmap for Bali tourism recovery in the new normal era, and then implement it holistically and sustainably.

3) Each element of the penta-helix needs to participate and optimize its role in Bali's tourism recovery considering that the Balinese economy (both macro and micro) is still highly dependent on tourism. Further research is needed on the policy framework to map in more detail the derivatives of these policies into programs and activities. In addition, it is necessary to develop a penta-helix partnership model in Bali tourism recovery so that it can be used as a guide. 


\section{Acknowledgement}

The authors wish to thank to Udayana University for the financial support.

\section{REFERENCES}

Antara, M., \& Sumarniasih, M.S. (2017). Role of Tourism in Economy of Bali and Indonesia. Journal of Tourism and Hospitality Management, 5(2), 34-44. https://doi.org/10.15640/jthm.v5n2a4

Bull, A. (1991). The Economics of Travel and Tourism. Melbourne: Pitnam.

Dahliah, Kurniawan, A., \& Putra, A.H.P.K. (2020). Analysis and Strategy of Economic Development Policy for SMEs in Indonesia. The Journal of Asian Finance, Economics and Business, 7(5), 103-110. https://doi.org/10.13106/jafeb.2020.vol7.no5.103

Etzkowitz, H., \& Leydesdorff, L. (1995). The Triple Helix. University-Industry-Government Relations: A Laboratory for Knowledge Based Economic Development. EASST Review, 14(1), 14-19. https://ssrn.com/abstract=3480085

Etzkowitz, H., \& Leydesdorff, L. (2000). The Dynamics of Innovation: From National Systems and 'Mode 2' to a Triple Helix of University-Industry-Government Relations. Research Policy, 29(2), 109-123. http://dx.doi.org/10.1016/S0048-7333(99)00055-4

Jahid, J. 2019. Destinasi Wisata: Butuh Sinergi dan Peran Penta Helix. https://fajar.co.id/2019/06/17/destinasi-wisata-butuh-sinergi-danperanpenta-helix/amp

Kodhyat, H. (1998). Sejarah Pariwisata dan Perkembangannya di Indonesia. Jakarta: Gramedia.

Leob, S., Dynarski, S., McFarland, D., Morris, P., Reardon, S., \& Reber, S. (2017). Descriptive analysis in education: A guide for researchers. NCEE 2017-4023, March 2017.

Lindmark, A., Roos, M.N., \& Sturesson, E. (2009). Difficulties of Collaboration for Innovation - A study in the Oresund Region. Master Thesis. Sweden: Lund University.

Marpaung, H. (2002). Pengantar Pariwisata. Bandung: Alfabeta.

Ministry of National Development Planning of the Republic of Indonesia. (2021). Studi Pembelajaran Penanganan COVID-19 di Indonesia. Jakarta: Kementerian PPN/Bappenas

Ministry of Tourism and Creative Economy of the Republic of Indonesia. (2021). Protokol Perjalanan Wisatawan di Era New Normal Rencana Pembukaan Pariwisata di Bali.

Murphy, P.E. (1985). Tourism: A Community Approach. New York and London: Methuen.

Nyumba, T.O., Wilson, K., Derrick, C.J., \& Mukherjee, N. (2017). The use of focus group discussion methodology: Insight from two decades of application in conservation. Methods in Ecology and Evolution, 9(1), 20-32. https://doi.org/10.1111/2041-210X.12860

Paramita, I.B.G., \& Putra, I G.G.P.A. (2020). New Normal Bagi Pariwisata Bali di Masa Pandemi COVID 19. Pariwisata Budaya: Jurnal Ilmiah Pariwisata Agama dan Budaya, 5(2), 57-65.

Pitana, I.G., \& Diarta, I K.S. (2009). Pengantar Ilmu Pariwisata. Yogyakarta: Penerbit Andi.

Riyanto, A. (2018). Implikasi Kualitas Pelayanan Dalam Meningkatkan Kepuasan Pelanggan pda PDAM Cibadak Sukabumi. Jurnal Ecodemica, 2(1), 117-124.

Rizkiyah, P., \& Liyushiana, H. (2019). Sinergitas Pentahelix Dalam Pemulihan Pariwisata Pasca Bencana Erupsi Gunung Api Sinabung di Kabupaten Karo, Sumatera Utara. Jurnal IPTA, 7(2), 247-256.

Slamet, R., Nainggolan, B., Roessobiyatno, R., Ramdani, H., \& Hendriyanto, A. (2016). Strategi Pengembangan UKM Digital dalam Menghadapi Era Pasar Bebas. Jurnal Manajemen Indonesia, 16(2), 136-147.

Soekadijo, R. G. (2000). Anatomi Pariwisata. Jakarta: Penerbit PT Gramedia.

Soemaryani, I. (2016). Pentahelix Model to Increase Tourist Visit to Bandung and Its Surrounding Areas Through Huan Resource Development. Journal Academy of Strategic Management, 15, Special Issues 3.

Soritua, Y. (2015). Analysis of The Role of Tourism Sector to be the Main Income In The Region (A comparation study in the Tourism sector in Bali Province). Referensi, 3(2), 1-27.

Sunaryo, B. (2013). Kebijakan Pembangunan Destinasi Pariwisata Konsep dan Aplikasinya di Indonesia. Yogyakarta: Gava Media.

Suasih, N.N.R., \& Wijaya, P.Y. (2021). Kondisi Pariwisata Bali di Tengah Wabah COVID-19: Realitas dan Respons Kebijakan. In Membangun Ketangguhan Ekonomi pada Era Pandemi. Sambodo, M.T., Tenrini, R.H., Akbar, R. Badan Kebijakan Fiskal dan PT. Gramedia Pustaka Utama, Jakarta, 627-661.

Suasih, N.N.R., Saskara, I.A.N., \& Wijaya, P.Y. (2021). Community Mobilities in Indonesia during the COVID-19 Pandemic and the Case of Bali. In IRSA Book Series on Regional Development No.19 (Regional perspectives of COVID-19 in Indonesia), Resosudarmo, B.P., Mulyaningsih, T., Priyarsono, D.S., Pratomo, D., Yusuf, A.A. IRSA: Jawa Barat. 76-95.

Suasih, N.N.R., Saskara, I.A.N., Yasa, I N.M., \& Budhi, M.K.S. (2017). Which One is Stronger to Affect Innovation Adoption by Balinese Farmers: Government Role or Local Wisdom? Journal of Sustainable Development, 10(3), 93-104. https://doi.org/10.5539/jsd.v10n3p93

Sugihamretha, I.D.G. (2020). Respon Kebijakan: Mitigasi Dampak Wabah Covid-19 Pada Sektor Pariwisata. The Indonesian Journal of Development Planning, IV(2), 191-206.

Vani, R.V., Priscilia, S.O., \& Adianto. (2020). Model Pentahelix Dalam Mengembangkan Potensi Wisata di Kota Pekanbaru. Publikauma: Jurnal Ilmu Administrasi Publik UMA, 8(1), 63-70.

Wang, J. \& Wang, Z. (2020). Strengths, Weaknesses, Opportunities and Threats (SWOT) Analysis of China's Prevention and Control Strategy for the COVID-19 Epidemic. International Journal of Environmental Research and Public Health, 17, 2235, 1-17. http://dx.doi.org/10.3390/ijerph17072235

Wijaya, P.Y., Kawiana, I.G.P., Suasih, N.N.R., Hartati, P.S., \& Sumadi, N.K. (2020). SWOT and MICMAC analysis to determine the development strategy and sustainability of the Bongkasa Pertiwi Tourism Village, Bali Province, Indonesia. Decision Science Letter, 9(2020), 439-452.

Wijaya, P.Y., \& Suasih, N.N.R. (2020). Peran Local Celebrity Endorsement pada Iklan di Media Sosial Terhadap Pembelian Produk Kuliner di Provinsi Bali pada Masa Stay Home Akibat Pandemi COVID-19. Jurnal Bisnis Strategi, 29(2), 119-133.

*** Statistics Indonesia (Badan Pusat Statistik). (2020). Pertumbuhan Ekonomi Indonesia Triwulan II-2020. Berita Resmi Statistik, No. 64/08/Th.XXIII, 5 Agustus 2020.

*** Statistics of Indonesia of Bali Province. (2021). Berita Resmi Statistik Provinsi Bali, No. 42/07/51/Th. XV, 1 Juli 2021. 